\title{
HUBUNGAN LAMA PAPARAN DAN MASA KERJA DENGAN KELUHAN PERNAPASAN PADA PEKERJA KOPRA DI DESA BARAT LAMBONGAN
}

\author{
${ }^{1}$ Andi Rizky Amaliah \\ ${ }^{2}$ Nur Ningsi
}

\author{
${ }^{1}$ Sekolah Tinggi Ilmu Kesehatan Makassar,Indonesia \\ ${ }_{2}^{2}$ Sekolah Tinggi Ilmu Kesehatan Makassar,Indonesia
}

\begin{abstract}
Alamat Korespondensi:
Nama Koresponden

: Andi Rizky Amaliah

Bagian

: Kesehatan Masyarakat

Institusi penulis

: Sekolah Tinggi Ilmu Kesehatan Makassar

No.Hp / Telfn

: 085329999299

:qkyrizkyamaliah@yahoo.com

Email penulis
\end{abstract}




\begin{abstract}
ABSTRAK
Pengasapan kopra merupakan salah satu produk turunan kelapa yang sangat penting karena merupakan bahan baku pembuatan minyak kelapa. Adanya proses pengasapan kopra di Desa Barat Lambongan Kabupaten Kepulauan Selayar berisiko terjadinya pencemaran udara di lingkungan. Tujuan penelitian adalah untuk mengetahui hubungan lama paparan dengan keluhan pernapasan dan untuk mengetahui hubungan masa kerja dengan keluhan pernapasan.Penelitian ini menggunakan metode observasional analitik dengan pendekatan cross sectional study dengan uji statistik yang dilakukan pada 68 orang pekerja kopra sebagai sampel. Tehnik pengambilan sampel yang dilakukan adalah total sampling. Data yang diperoleh dalam penelitian diolah dengan menggunakan program SPSS serta dilakukan analisis univariat dan bivariat dengan menggunakan statistik uji chi square dengan uji alternatif fisher's exact dan pearson chi-square. Hasil penelitian, menunjukkan bahwa ada hubungan antara lama paparan nilai $p 0,00(\leq 0,05)$ dengan keluhan pernapasan, dan tidak ada hubungan masa kerja nilai $p 0,06(>0,05)$ dengan keluhan pernapasaan pada pekerja kopra. Keluhan pernapasan pada pekerja kopra di Desa Barat Lambongan Kabupaten Kepulauan Selayar di pengaruhi oleh lama paparan. Saran dari penelitian ini adalah pihak industri pengasapan kopra untuk menyediakan masker sebagai upaya dalam mencegah adanya gangguan pernapasan serta bagi pihak puskesmas untuk melakukan kegiatan puskesmas keliling rutin khususnya mengunjungi pekerja kopra.
\end{abstract}

\title{
Kata Kunci : Keluhan Pernapasan, Lama Paparan, Masa Kerja
}

\begin{abstract}
Fumigation of copra is one of coconut derivative products which is very important because it is the raw material in creating coconut oil. The process of copra fumigation in the Barat Lambongan Village, Kepulauan Selayar is a risk to lead air pollution in the environment. This study aimed to recognize the associationof exposure duration with respiratory complaints as well as the associationof working period with respiratory complaints. This was observational analytic method with cross sectional study design in that number of sample was 68 copra workers selected by total sampling. Data analysis applied SPSS program and univariate and bivariate analysis was performed by chi square test statistics with alternative test fisher's exact and Pearson chi-square. The results revealed that there was anassociationof the length of exposure by $p$ value $0.00(\leq 0.05)$ with respiratory complaints, while working period did not relate to breathing complaints in copra workersby p value 0.06 (> 0.05). It concluded that respiratory complaints on copra workers in Barat Lambongan Village, Selayar were influenced by exposure time. It is encouraged to fumigation industry to provide masks as an effort to prevent respiratory problems, and tohealth centers toconduct routine mobile health center activities, especially visiting copra workers.
\end{abstract}

Keywords: Respiratory Complaints, Length Of Exposure, Employment Period 


\section{PENDAHULUAN}

Keluhan pernapasan merupakan adanya gangguan pada saluran pernapasan akibat selalu terpapar polutan udara. Semakin lama individu terpapar polutan udara maka kemungkinan adanya keluhan pernapasan semakin besar. Keluhan pernapasan yang terjadi pada seseorang seperti batuk, berdahak, batuk berdahak, sesak napas, napas berbunyi (mengi) dan flu serta penyakit pada dada dapat dijadikan tanda dini terjadinya kerusakan pada paru. Keluhan pernapasan yang paling banyak dikeluhkan adalah batuk, sesak napas dan flu (Depkes RI, 2004) dalam Prasetya,2016.

Badan dunia International Labour Organization (ILO) mengemukakan penyebab kematian yang diakibatkan oleh pekerjaan adalah penyakit kanker sebesar $34 \%$, kecelakaan kerja $25 \%$, penyakit saluran pernapasan $21 \%$, penyakit kardiovaskuler $15 \%$, dan $5 \%$ disebabkan oleh faktor lain (Hafsari, 2016 ).

Salah satu gangguan saluran pernapasan adalah Infeksi saluran pernapasan akut (ISPA) yang merupakan masalah kesehatan yang utama dibuktikan dengan prevalensi ISPA di Indonesia sebanyak 25,0\% (rentang: $17 \%-39 \%$ ). Prevalensi ISPA Indonesia menurut Riskesdas 2013 (25\%) tidak jauh berbeda dengan 2007 (25,5\%) dengan 16 provinsi di antaranya mempunyai prevalensi di atas angka nasional (Riskesdas, 2013). Hasil riskesdas tahun 2013 prevalensi ISPA di Sulawesi Selatan sebesar $6,8 \%$. Berdasarkan profil kesehatan kota Makassar tahun 2015 pola penyakit terbanyak di rumah sakit umum maupun data survey menunjukkan tingginya kasus ISPA dengan jumlah kasus sebanyak 120.153 kasus.

Berdasarkan data yang diperoleh dari badan pusat statistik Kabupaten Kepulaun Selayar tahun 2016, menunjukkan bahwa jumlah kasus penyakit terbanyak di Kebupaten Kepulauan Selayar adalah gangguan pernapasan dimana jumlah penyakit ISPA menduduki peringkat pertama yaitu sebanyak 21.868 kasus. Menurut Anderson (1998) dalam Hafsari (2016) pekerja yang telah bekerja > 5 tahun berpotensi mengalami gangguan fungsi paru lebih besar dibandingkan dengan pekerja yang memiliki masa kerja < 5 tahun.

Berdasarkan Hasil penelitian yang dilakukan oleh Eko Novia Putri (2016) di kecamatan Ungaran Timur. Ada hubungan antara unsur pencemar udara dengan keluhan subjektif pernapasan. Ada hubungan antara pemakaian APD masker dengan keluhan subjektif pernapasan pada pekerja. Penelitian lain yang dilakukan Poppy Fujianti tahun 2015 mengenai faktor-faktor yang mempengaruhi timbulnya keluhan gangguan pernapasan jati berkah kota Jambi menyatakan bahwa ada hubungan antara keluhan gangguan 
pernapasan dengan umur pekerja, masa kerja, lama paparan dan penggunaan APD. Dan penelitian yang dilakukan Prasetya tahun 2016 yang meyebutkan bahwa, terdapat keluhan pada saluran pernapasan sebesar $75 \%$ dari total responden 80 orang. Berdasarkan dari uraian diatas peneliti tertarik melakukan penelitian mengenai hubungan paparan asap dengan keluhan pernapasan pada pekerja kopra di Desa Barat Lambongan Kabupaten Kepualauan Selayar karena belum ada penelitian sebelumnya yang meneliti tentang hubungan paparan asap dengan keluhan pernapasan pada pekerja kopra.

\section{METODE}

Penelitian ini merupakan observasional analitik dengan pendekatan crosssectional study, yaitu untuk mengetahui hubungan lama paparan dan masa kerja dengan keluhan pernapasan pada pekerja kopra, mengumpulkan datadata mengenai lama paparan dan masa kerja. Penelitian ini dilakukan untuk mengetahui hubungan antara lama paparan dan masa kerja dengan keluhan pernapasan pada pekerja kopra. Penelitian ini dilakukan di Desa Barat Lambongan Kabupaten Kepulauan Selayar. Waktu penelitian ini dilaksanakan pada tanggal 25 Juli - 23 Agustus 2018. Populasi dalam penelitian ini adalah semua pekerja kopra yang berada di Desa Barat Lambongan Kabupaten Kepulauan Selayar yang berjumlah 68 pekerja kopra. Sampel pada penelitian ini adalah 68 orang pekerja kopra di Desa Barat Lambongan Kabupaten Kepulauan Selayar. Sampel ditarik secara total sampling sebesar 68 orang. Pengumpulan data dilakukan dengan menggunakan lembar kuesioner. Data yang telah dikumpulkan kemudian diolah secara manual dan dengan menggunakan program SPSS meliputi editing, coding, cleaning, entry data dan analysis data. Hasil pengolahan data disajikan dalam bentuk tabel dan narasi.

\section{HASIL}

Tabel 1 menunjukkan bahwa karakteristik responden berdasarkan umur yang paling banyak mengalami keluhan pernapasan yaitu pada kelompok umur 6474 tahun sebanyak 3 orang (100,0\%), karakteristik responden berdasarkan jenis kelamin laki-laki yang mengalami keluhan pernapasan sebanyak 28 orang $(77,8 \%)$ dan jenis kelamin perempuan yang mengalami keluhan pernapasan sebanyak 28 orang $(87,5 \%)$ dan karakteristik responden berdasarka tingkat pendidikan yang paling banyak mengalami keluhan pernapasan yaitu pada tingkat tidak sekolah sebanyak 12 orang $(100,0 \%)$ dan tidak tamat SD sebanyak 6 orang $(100,0 \%)$.

Tabel 2 menunjukkan bahwa responden dengan keluhan pernapasan paling banyak adalah ada keluhan pernapasan sebanyak 56 orang $(82,4 \%)$ dan 
reponden dengan tidak ada keluhan pernapasan sebanyak 12 orang $(17,6 \%)$. Responden dengan lama paparan paling banyak adalah tidak lama paparan sebanyak 29 orang (42.6\%) dan responden dengan lama paparan asap sebanyak 39 orang $(57,4 \%)$. Masa kerja responden paling banyak mempunyai masa kerja baru sebanyak 28 orang $(41,2 \%)$ dan yang memiliki masa kerja lama sebanyak 40 orang $(58,8 \%)$. Semua responden dalam penelitian ini tidak ada yang menggunakan APD.

Tabel 3 menunjukkan bahwa jenis keluhan paling banyak yaitu batuk sebanyak 33 orang $(22,3 \%)$ dan yang mengalami dua jenis keluhan pernapasan yang paling banyak yaitu batuk dan flu sebanyak 18 orang (12,2\%) dan yang mengalami keluhan pernapasan ketiganya sebanyak 8 orang $(5,4 \%)$.

Table 4 menunjukkan bahwa dari 39 responden dengan lama paparan lama dan ada keluhan pernapasan sebanyak 38 orang $(97,4 \%)$. Responden dengan lama paparan lama dan tidak ada keluhan pernapasan sebanyak 1 orang (2,6\%). Dari 29 responden dengan lama paparan tidak lama dan ada keluhan pernapasan sebanyak 18 orang $(62,1 \%)$ dan responden dengan lama paparan tidak lama dan tidak ada keluhan pernapasan sebanyak 11 orang (37,9\%). Berdasarkan uji statistik chi square dengan alternatif pearson chi-square diketahui nilai p 0,00 maka dapat dikatakan ada hubungan antara lama paparan dengan keluhan pernapasan.

Table 5 menunjukkan bahwa, dari 28 orang responden dengan masa kerja baru dan keluhan pernapasan ada sebanyak 20 orang $(71,4 \%)$ dan responden dengan masa kerja baru dan tidak ada keluhan pernapasan sebanyak 8 orang $(28,6 \%)$. Dari 40 responden dengan masa kerja lama dan ada keluhan pernapasan sebanyak 36 orang (90,0\%), responden dengan masa kerja lama dan tidak ada keluhan pernapasan sebanyak 4 orang $(10,0 \%)$. Berdasarkan uji statistik diketahui nilai $p$ 0,06 maka dapat dikatakan tidak ada hubungan antara masa kerja dengan keluhan pernapasan.

\section{PEMBAHASAN}

Lama paparan perhari menentukan dosis harian yang diterima pekerja. Semakin lama paparan, maka semakin besar pula dosis pajanan asap yang diterima. Sebagai catatan bahwa salah satu lokasi kerja berisiko memiliki pajanan harian melebihi NAB. Apabila pekerja bekerja dilokasi tersebut pada $\geq 8$ jam. Maka ia akan berisiko megalami gejala gangguan pernapasan dalam jangka waktu kedepan (Poppy Fujianti 2016).

Berdasarkan hasil penelitian menunjukkan bahwa responden yang memiliki lama paparan lama dan ada keluhan pernapasan sebanyak 38 pekerja $(97,4 \%)$, respoden yang memiliki lama 
paparan lama dan tidak ada keluhan pernapasan sebanyak 1 pekerja $(2,6 \%)$ dan responden dengan lama paparan tidak lama dan ada keluhan pernapasan sebanyak 18 pekerja $(62,1 \%)$ dan responden dengan lama paparan tidak lama dan tidak ada keluhan pernapasan sebanyak 11 pekerja (37,9\%). Berdasarkan uji statistic dengan uji fisher's exact, di dapat nilai $p 0,00 \leq$ 0,05 sehingga dapat di katakan ada hubungan antara lama paparan dengan keluhan pernapasan. Semakin lama pekerja kopra terpapar dengan asap maka memungkinkan adanya keluhan pernapasan dan semakin tidak lama pekerja kopra terpapar asap maka kemungkinan tidak akan menimbulkan keluhan pernapasan.

Umumnya dalam satu hari seseorang bekerja dengan baik sekitar 6-10 jam, jika seseorang bekerja lebih dari 8 jam maka semakin lama seseorang bekerja maka semakin banyak orang tersebut terpapar polutan udara yang ditimbulkan dari lingkungan kerja. Seseorang yang terlalu lama kontak dengan udara yang mengandung polutan (Dewi Sinta Purnama 2015).

Hasil penelitian ini sejalan dengan penelitian Hamzah Hazyim dan Poppy Fujianti yang menyatakan bahwa ada hubungan lama paparan dengan keluhan pernapasan dan hasil penelitian Dwi Sinta Nirmala yang menyatakan bahwa pekerja yang bekerja 8 jam sehari memiliki keluhan kesehatan lebih tinggi dibandingkan dengan pekerja 8 jam sehari dimana 19 pekerja (90,5\%) mengalami keluhan sesak nafas. Hasil penelitian tersebut sesuai dengan hasil penelitian ini. Hasil penelitian menyatakan bahwa ada hubungan antara lama paparan dengan keluhan pernapasan pada pekerja kopra di Desa Barat Lambongan Kabupaten Kepulauan Selayar. Hal ini dibuktikan dengan uji fishers exact yang menunjukkan nilai $p$ value 0,00 .

Hasil penelitian ini tidak sejalan dengan penelitian Topan Agung dan Ratih Andika yang menyatakan bahwa tidak ada hubungan antara paparan asap dengan keluhan gangguan pernapasan. Dimana nilai $\mathrm{p}$ value yang diperoleh adalah 0,699. Menurut Horington dan Gill (2005) lama bekerja adalah durasi waktu untuk melakukan suatu kegiatan/pekerjaan setiap harinya yang dinyatakan dalam satuan jam. Lama seseorang bekerja dengan baik dalam sehari pada umumnya 8 jam (Horington dan Gill dalam Topan Agung dan Ratih Andika 2016) .

Masa kerja adalah suatu kurun waktu atau lamanya tenaga kerja itu bekerja di suatu tempat. Masa kerja dapat mempengaruhi kinerja baik positif maupun negative. Memberi pengaruh positif pada pekerja bila dengan semakin lamanya masa kerja tenaga kerja semakin berpengalaman dalam melaksanakan tugasnya. Sebaliknya akan memberi pengaruh negative apabila 
dengan semakin lamanya masa kerja maka akan timbul kebiasaan pada tenaga kerja. Hal ini biasanya terkait dengan pekerjaan yang bersifat monoton dan berulang-ulang (M.A Tulus 1992:211 dalam Riska 2013).

Menurut Morgan dan Parkes dalam Ratih (2016), waktu yang dibutuhkan seseorang yang terpapar kontaminan pencemar udara untuk terjadinya gangguan pernapasan yaitu lebih dari lima tahun. Hal ini tidak sesuai dengan hasil yang diperoleh yang menyebutkan bahwa pekerja kopra dengan masa kerja lebih dari 5 tahun sebagian besar mengalami keluhan gangguan pernapasan.

Berdasarkan hasil penelitian menunjukkan bahwa responden yang memiliki masa kerja baru dan ada keluhan pernapasan sebanyak 20 pekerja $(71,4 \%)$, respoden yang memiliki masa kerja baru dan tidak ada keluhan pernapasan sebanyak 8 pekerja $(28,6 \%)$ dan responden dengan masa kerja lama dan ada keluhan pernapasan sebanyak 36 pekerja $(90,0 \%)$ dan responden dengan masa kerja lama dan tidak ada keluhan pernapasan sebanyak 4 pekerja $(10,0 \%)$. Berdasarkan uji statistic dengan uji fisher's exact, di dapat nilai $p$ value $0,06 \leq 0,05$ sehingga dapat di katakan tidak ada hubungan antara masa kerja dengan keluhan pernapasan.

Dari hasil analisis hubungan masa kerja dengan keluhan pernapasan berdasarkan hasil uji fisher's exact diperoleh $p$ value $0,06 \leq 0,05$. Karena $p$ value lebih kecil dari 0,05 dengan demikian Ha di tolak, yang berarti tidak ada hubungan masa kerja dengan keluhan pernapasan pada pekerja kopra di Desa Barat Lambongan Kabupaten Kepulauan Selayar.

Hasil penelitian ini tidak sejalan dengan penelitian Poppy Fujianti yang menyatakan bahwa ada hubungan masa kerja dengan keluhan pernapasan. Hasil penelitian tersebut tidak sesuai dengan hasil penelitian ini. Hasil penelitian menyatakan bahwa tidak ada hubungan antara masa kerja dengan keluhan pernapasan pada pekerja kopra di Desa Barat Lambongan Kabupaten Kepulauan Selayar. Hal ini dibuktikan dengan uji fishers exact yang menunjukkan nilai $p$ value 0,06 .

Hasil penelitian ini sejalan dengan penelitian Hartini tahun 2016 yang menyatakan bahwa tidak ada hubungan antara masa kerja dengan keluhan subjektif pernapasan pada pekerja di industri panagasapan ikan Kecamatan Ungaran Timur. Semakin lama seseorang bekerja maka semakin tinggi pula paparan bahaya yang dialami oleh seseorang tersebut .

Kondisi udara dilingkungan sekitar pengasapan kopra tentu akan memberikan dampak yang buruk bagi kesehatan masyarakat yang bertempat tinggal dan beraktivitas di lingkungan tersebut. Sumber pencemar udara akan masuk kedalam tubuh 
manusia melalui jalan pernapasan sehingga akan timbul keluhan pernapasan (Hartini 2016).

\section{KESIMPULAN}

Berdasarkan hasil penelitian dapat disimpulkan bahwa : Ada hubungan lama paparan dengan keluhan pernapasan pada pekerja kopra. Tidak ada hubungan masa kerja dengan keluhan pernapasan pada pekerja kopra. Adapun saran yang dapat diberikan dalam penelitian ini yaitu Bagi pihak industri pengasapan kopra di Desa Barat Lambongan Kabupaten Kepulauan Selayar untuk menyediakan masker sebagai upaya dalam pencegahan penyakit gangguan pernapsan pada pekerja kopra di Desa Barat Lambongan Kabupaten Kepulauan Selayar. Bagi pihak puskesmas untuk melakukan kegiatan puskesmas keliling rutin khususnya mengunjungi pekerja kopra di Desa Barat Lambongan Kabupaten Kepulauan Selayar. Bagi pihak puskesmas sebaiknya memberikan pendidikan kesehatan tentang penggunaan APD sehingga dapat meminimalisir terjadinya keluhan pernapasan.

\section{DAFTAR PUSTAKA}

Awaluddin.2016.Keluhan Kesehatan Masyarakat Akibat Kabut Asap Kebakaran Hutan Dan Lahan Di Kota Pekanbaru.Journal Endurance 1(1) 25 Februari 2016 (37-46)
Badan Pusat Statistic Kebupaten Kepulauan Selayar.Tahun 2016. Kepulauan Selayar Dalam Angka.

Esha,Indi.2017.Analisis Paparan Gas Polutan Karbon Monoksida Terhadap Fungsi Paru Petugas Parkir Di Ruang Bawah Tanah Mal X Kota Pekanbaru. Jurnal Ilmu Lingkungan 2017

Hasyim Hamah, Fujianti, Dan Sunarsih Elvi.2012. Factor-Faktor Yang Mempengaruhi Timbulnya Gangguan Keluhan Pernapasan Pada Pekerja Mebel Jati Berkah Kota Jambi Tahun 2012. 6: 03 November 2015. Artikel Penelitian

Hartini, Eko Dan Perdani, Eka Novia P.A. 2016. Faktor-Faktor Yang Berhubungan Dengan Keluhan Subjektif Pernapasan Pada Pekerja Di Industry Pengasapan Ikan Kecamatan Ungaran Timur Tahun 2016. Pdf.

Mukono,H.J.2013. Pencemaran Udara Dan Pengaruh Terhadap Gangguan Saluran Pernapasan. Cetakan Kedua. Airlangga University Press.Surabaya

Muthe, E.L .Dkk 2014. Dampak Pajanan Asap Lilin Batik (Malam) Terhadap Fungsi Paru Dan Asma Kerja Pada Pekerja Industry Batik Tradisional. J Respire Indo Vol. 34 No. 3 Juli 2014

Nirmala,D.A Dan Prasasti,C,I.2015. Konsentrasi Pm 2,5 Dan Analisis Karakteristik Pekerja Terhadap Keluhan Kesehatan Pekerja Pengasapan Ikan Di Kelurahan Tambak Wedi Surabaya. Jurnal Kesehatan Lingkungan Vol. 8 No. 1 Januari 2015

Puji E., Syatriani S., Bustan MN., dan Efendi S. 2017. Pedoman Penulisan Skripsi. 15. Cetakan ketigabelas. Makassar 
Poppy Fujianti.2012. Factor-Faktor Yang Mempengaruhi Timbulnya Gangguan Keluhan Pernapasan Pada Pekerja Mebel Jati Berkah Kota Jambi Tahun 2012. 6 : 03 November 2015. Artikel Penelitian.

Profil Kesehatan Prov. Sulawesi Selatan Tahun 2016.

Profil Kesehatan Indonesia Tahun 2014

Profil Kesehatan Kota Makassar Tahun 2015

Premana,P.M.I. Dan Griadhi,I.P.A. 2017. Prevalensi Gangguan Fungsi Paru Akibat Paparan Asap Pada Pedagang Sate Di Denpasar. E Journal. Medika, Vol. 6. No 6 Juni 2017Ratih,Andika A.R Dan Topan Agung E.P.2016. Pengaruh Paparan Ch4 Dan H2s Terhadap Keluhan Gangguan Pernapasan Pemulung Di TPA Mrican Kebupaten Ponorogo. Journal Of Industrial Hygiene And Occupational Health Vol.1 No. 1 Oktober 2016

Riset Kesehatan Dasar (Riskesdas) Tahun 2013

Rose,K.D.C.Dan Teuleka,A.R.2014. Penilaian Resiko Paparan Asap Kendaraan Bermotor Pada Polentas Polrestabes Surabaya.The Indonesian
Journal Of Occupational Safety And Health, Vol. 3 No. 1 Jan-Jun 2014

Sandra. Christiana.2013. Pengaruh Penurunan Kualitas Udara Terhadap Fungsi Paru Dan Keluhan Pernapasan Pada Polisi Lalu Lintas Polwiltabes Surabaya. Jurnal Ikesmas Vo. 9 No. 1 Maret 2013

Sinta,Nirmala Dewi. 2015. Konsentrasi P.M.5 Dan Analisis Karekteristik Pekerja Terhadap Keluhan Kesehatan Pekerja Pengasapan Ikan Di Kelurahan Tambak Wedi Surabaya.Jurnal Kesehatan Lingkungan Vol.8, No,1 Januari 2015:57-68

Soekidjo,Notoatmodjo. 2012. Metodologi Penelitian. Revisi. Pt Rineka Cipta. Jakarta 
Tabel 1. Distribusi Keluhan Pernapasan berdasarkan Karakteristik Responden

\begin{tabular}{lcccccc}
\hline \multirow{2}{*}{ Karakteristik Responden } & \multicolumn{3}{c}{ Keluhan Pernapasan } & \multicolumn{3}{c}{ Total } \\
\cline { 2 - 7 } & Ada & \% & Tidak ada & \% & n & \% \\
\hline Umur (Tahun) & & & & & & \\
$20-30$ & 9 & 56,2 & 7 & 43,8 & 16 & 100,0 \\
$31-41$ & 16 & 84,2 & 3 & 15,8 & 19 & 100,0 \\
$42-52$ & 17 & 94,4 & 1 & 5,6 & 18 & 100,0 \\
$53-63$ & 11 & 91,7 & 1 & 8,3 & 12 & 100,0 \\
44-74 & 3 & 100,0 & 0 & 0,0 & 3 & 100,0 \\
\hline Jenis Kelamin & & & & & & \\
Laki-laki & 28 & 77,8 & 8 & 22,2 & 36 & 100,0 \\
Perempuan & 28 & 87,8 & 4 & 12,5 & 32 & 100,0 \\
\hline Pendidikan & & & & & & \\
TIDAK SEKOLAH TIDAK & 12 & 100,0 & 0 & 0,0 & 12 & 100,0 \\
TAMAT SD & 6 & 100,0 & 0 & 0,0 & 6 & 100,0 \\
SD & 24 & 88,9 & 3 & 11,1 & 27 & 100,0 \\
SMP & 5 & 83,3 & 1 & 16,7 & 6 & 100,0 \\
SMA & 9 & 52,9 & 8 & 47,1 & 17 & 100,0 \\
\hline
\end{tabular}

Tabel 2. Distribusi Frekuensi Keluhan Pernapasan, Lama Paparan dan Masa Kerja Pada Pekerja Kopra

\begin{tabular}{lcc}
\hline \multicolumn{1}{c}{ Variabel } & n & \% \\
\hline Keluhan Pernapasan & & \\
Ada & 56 & 82,4 \\
Tidak Ada & 12 & 17,0 \\
\hline Lama Paparan (jam/hari) & & \\
Tidak Lama ( $\leq 8)$ & 29 & 41,2 \\
Lama (>8) & 39 & 58,8 \\
\hline Masa Kerja (tahun) & & 41,2 \\
Baru (<5) & 28 & 58,8 \\
Lama ( $\geq 5)$ & 40 & 0 \\
\hline Penggunaan APD & & 100,0 \\
Ya & 0 & $\mathbf{1 0 0 , 0}$ \\
Tidak & 68 & \\
\hline Jumlah & $\mathbf{6 8}$ & \\
\hline
\end{tabular}

Tabel 3. Distribusi Keluhan Pernapasan pada Pekerja Kopra

\begin{tabular}{lcc}
\hline \multicolumn{1}{c}{ Keluhan pernapasan } & N & \% \\
\hline Batuk & 33 & 22,3 \\
Sesak napas & 30 & 20,3 \\
Flu & 31 & 20,9 \\
Batuk dan sesak napas & 13 & 8,8 \\
Batuk dan flu & 18 & 12,2 \\
Sesak napas dan flu & 15 & 10,1 \\
Batuk, sesak napas dan flu & 8 & 5,4 \\
\hline Total & $\mathbf{6 8}$ & $\mathbf{1 0 0 , 0}$ \\
\hline
\end{tabular}


Tabel 4. Distribusi Keluhan Pernapasan Berdasarkan Lama Paparan Pada Pekerja Kopra

\begin{tabular}{|c|c|c|c|c|c|c|c|}
\hline \multirow{3}{*}{$\begin{array}{c}\text { Lama Paparan } \\
\text { (jam/hari) }\end{array}$} & \multicolumn{4}{|c|}{ Keluhan Pernapasan } & \multicolumn{2}{|c|}{ Total } & \multirow[t]{2}{*}{ P Value } \\
\hline & \multicolumn{2}{|c|}{ Ada } & \multicolumn{2}{|c|}{ Tidak Ada } & & & \\
\hline & $\mathbf{n}$ & $\%$ & $\mathbf{n}$ & $\%$ & $\mathbf{n}$ & $\%$ & \\
\hline Lama & 38 & 97,4 & 1 & 2,6 & 39 & 57,4 & 0,00 \\
\hline Tidak Lama & 18 & 62,1 & 11 & 37,9 & 29 & 42,6 & \\
\hline Total & 56 & 82,4 & 12 & 17,6 & 68 & $\overline{100,0}$ & \\
\hline
\end{tabular}

Tabel 5. Hubungan Masa Kerja Dengan Keluhan Pernapasan pada Pekerja Kopra

\begin{tabular}{lccccccc}
\hline \multirow{2}{*}{$\begin{array}{c}\text { Masa Kerja } \\
\text { (Tahun) }\end{array}$} & \multicolumn{3}{c}{ Keluhan Pernapasan } & & Total & \multirow{2}{*}{ P Value } \\
\cline { 2 - 7 } & \multicolumn{2}{c}{ Ada } & \multicolumn{2}{c}{ Tidak Ada } & & \\
\cline { 2 - 7 } & $\mathbf{N}$ & $\mathbf{\%}$ & $\mathbf{n}$ & $\mathbf{\%}$ & $\mathbf{n}$ & $\mathbf{\%}$ & \multirow{2}{*}{0,06} \\
\hline Baru & 20 & 71,4 & 8 & 28,6 & 28 & 41,2 \\
\hline Lama & 36 & 90,0 & 4 & 10,0 & 40 & 58,8 \\
\hline Total & $\mathbf{5 6}$ & $\mathbf{8 2 , 4}$ & $\mathbf{1 2}$ & $\mathbf{1 7 , 6}$ & $\mathbf{6 8}$ & $\mathbf{1 0 0 , 0}$ & \\
\hline
\end{tabular}

